\title{
Influence of corn forage type and flaxseed on the productive parameters, meat quality and sensory analysis in Pelibuey lambs
}

\author{
Diana Tamara Ramírez', José Reyes Galaviz-Rodriguez², Xochitl Gabriela Montalvo-Aguilar², \\ Patricia Villalobos-Peñalosa ${ }^{2}$, Pablo Cortés-Roldán², Luz Marina Hernández-Calva ${ }^{2 *}$ \\ ${ }^{1}$ College of Agriculture. California State University, Chico. 400 West First Street. Chico, CA 95929, USA, ${ }^{2}$ Facultad de Agrobiología. Medicina \\ Veterinaria y Zootecnia. Universidad Autónoma de Tlaxcala. Ex-Hacienda de Xalpatlahuaya. Huamantla, 90513, Tlaxcala. México
}

\section{A B S T R A C T}

The effect of corn straw (CS) or silage (CL), combined with flaxseed (Fx) on meat quality production and sensory analysis of Pelibuey lambs were evaluated. Sixty-four Pelibuey lambs were divided to each of the following treatments: T1) Corn Straw (CS: 16.3\%) without flaxseed (Fx) in the diet, T2) CS plus $6 \%$ of Fx, T3) Corn silage (CL: 15\%) without Fx and T4) CL plus $6 \%$ of Fx. Dry matter intake improved by $9.2 \%$ with $C L$ vs. CS. The feed conversion improved with the use of $C L$ in $1-14 d(P \leq 0.02)$ and $14-28 d(0.05)$ in $11.7 \%$ and $10.4 \%$, respectively. Coordinate $b$ was increased by $38 \%(P=0.01)$ in the animals fed with CS. Thus results show that Fx did not influence the physical-chemical and sensory variables of the meat. CL favorably changed the feed intake, flavor and juiciness of the meat, as in the fattening of lambs.

Keywords: Corn straw; Corn silage; Flaxseed; Lambs, Meat

\section{INTRODUCTION}

The increase per capita of meat consumption worldwide has cause developing countries to increase their production rate to 2\% (FAO 2013). At the same time, there was also an increase in the demand of better meat quality. Consumers request more juiciness, tenderness, less cholesterol content and saturated fatty acids on the everyday meat. (Della Malva et al., 2016). In production systems, lamb (ovis aries) grazing improves the content of $\alpha$-linolenic acid in meat, compared to feeding lambs with high grain diets (French et al., 2000). However, in some regions of the world, grazing is difficult due to problems of land tenure or disorganization for the use of communal lands. In some regions of developing countries, the grain produced by farmers is not adequately paid for; consequently, they choose to include them in the diets of their animals destined for meat production.

Specifically, in the central highlands of Mexico, corral intensive feedings of lambs have increased. The butchers demand animals with a minimum weight of $40 \mathrm{~kg}$, young and well formed so that the carcass yields at least 50\% and with little fat, with a good sensory quality of the meat for consumers satisfaction. Some work done in cattle, indicates that corn silage has improved the performance of animals and improved the sensory acceptability of meat (Hernández-Calva et al., 2011). In the case of lambs, data on some supplements with forages and oils included in the feeding ration have been shown beneficial. But, data on the use of flaxseed and forage type is scarce. In Mexico as in other countries, corn forage is highly available as silage or hay. The objective of the present study was to evaluate silage and corn straw, as one of the main available forages, combined with flaxseed on the productive characteristics of the lambs, carcass yield and sensory quality of the meat.

\section{MATERIAL AND METHODS}

\section{Animals and distribution}

Sixty-four male Pelibuey lambs of 7 months old were selected. These were housed in the experimental farm

\footnotetext{
*Corresponding autor:

Luz Marina Hernandez-Calva, Facultad de Agrobiología. Medicina Veterinaria y Zootecnia. Universidad Autónoma de Tlaxcala. Ex-Hacienda de Xalpatlahuaya. Huamantla, Tlaxcala. México. C.P. 90513 México. E-mail: marinahc@yahoo.com
} 
of Tlaxcala, Mexico (AEC 016). Subsequently, they were dewormed with Ivermectin (Ivomec ${ }^{\circledR}$, Bovines / Sheep Merial Laboratory Mexico) and vaccinated against clostridial diseases (Ultrabac7®, Schering-Plow Veterinary, Mexico). Adaptation to a diet with more than $50 \%$ grain was performed for 15 days (base diet in the experiment). The treatments used were as follows: T1) Corn Straw (CS: $16.3 \%$ ) without flaxseed ( $\mathrm{Fx})$ in the diet, T2) CS plus $6 \%$ of Fx, T3) Corn silage (CL: 15\%) without Fx and T4) CL plus $6 \%$ of Fx. All diets formulated on an iso-protein basis $(15.6 \%)$ and the composition of experimental diets is shown in Tables 1-5. The lambs were weighed and in each treatment they were assigned by homogeneous weight around $25 \mathrm{~kg}$, in 16 pens (four animals/pen), with repetitions of four pens per treatment. Each pen has an

Table 1: Composition of experimental diets with corn forage type and flaxseed level

\begin{tabular}{|c|c|c|c|c|}
\hline \multirow[t]{2}{*}{ Treatments } & T1 & T2 & T3 & T4 \\
\hline & \multicolumn{2}{|c|}{ Corn straw } & \multicolumn{2}{|c|}{ Corn silage } \\
\hline Ingredients, \% & $F x-0$ & Fx-6 & $\mathrm{Fx}-0$ & Fx-6 \\
\hline Corn, grain & 31.47 & 25.47 & 32.97 & 26.77 \\
\hline Wheat, grain & 28.0 & 28.0 & 28.0 & 28.0 \\
\hline Cane molasses & 12.8 & 12.6 & 12.8 & 12.8 \\
\hline Flaxseed (Fx) & & 6.0 & 0 & 6.0 \\
\hline Corn Straw & 16.3 & 16.3 & 0 & 10.5 \\
\hline Corn silage & & & 15.0 & 15.0 \\
\hline Limestone & 1.03 & 1.03 & 1.03 & 1.03 \\
\hline Urea & 1.0 & 1.2 & 0.8 & 1.0 \\
\hline Trace minerals ${ }^{a}$ & 0.4 & 0.4 & 0.4 & 0.4 \\
\hline \multicolumn{5}{|c|}{ Nutrimental composition (basis dry matter) } \\
\hline ME, Mcal/kg & 2.6 & 2.6 & 2.7 & 2.8 \\
\hline $\mathrm{NE}_{\mathrm{g}}, \mathrm{Mcal} / \mathrm{kg}$ & 1.1 & 1.1 & 1.2 & 1.2 \\
\hline Protein, \% & 15.5 & 15.6 & 15.6 & 15.6 \\
\hline NDF & 26.1 & 25.0 & 22.6 & 21.3 \\
\hline Calcium, \% & 0.6 & 0.60 & 0.6 & 0.6 \\
\hline Phosphorus, \% & 0.26 & 0.26 & 0.3 & 0.3 \\
\hline
\end{tabular}

a Trace mineral salt content: CoSO4, $0.068 \%$; CuSO4, $1.04 \%$; FeSO4, $3.57 \%$; ZnO, $1.24 \%$; MnSO4, $1.07 \%$; Kl, $0.052 \%$ and $\mathrm{NaCl}, 92.96 \%$ area of $2 \mathrm{~m}^{2}$, with shade, concrete floor, wooden chip bed, feeding trough and drinking fountain.

\section{Productive variables}

The feed samples were obtained homogeneously and dried in a forced air oven at a temperature of $100^{\circ} \mathrm{C}$ for $48 \mathrm{~h}$. (AOAC, 1990) Subsequently, the samples were mixed and at the end of the fattening a representative sample was obtained for the laboratory analysis. Dry matter intake (DMI) and average daily weight (ADG) were measured every 14 days. ADG of the animals was recorded during the fattening time from 7 to $9 \mathrm{am}$, using a digital scale with an accuracy of $\pm 10 \mathrm{~g}$, obtaining the average of three readings. ADG was obtained by the difference in final and initial weight divided between the days of each experimental period. Feed efficiency (FE) was estimated with DMI / ADG.

\section{Slaughtering}

Prior to slaughtering, the lambs were subjected to a $12 \mathrm{~h}$ fasting period. The procedure consisted of desensitizing each animal with a hidden pistol gun, then they were bled with a cut in the jugular. The variables recorded were slaughter weight, hot carcass weight and chilled carcass weight. Commercial performance was calculated. The weight readings were made with the same scale mentioned above. The eviscerated carcass was identified with a numbered bracelet, later they were introduced to a cold room at $4^{\circ} \mathrm{C}$. After 48h, they were dissected and cut transversely with a saw. The separation of the neck was made in the cut from the 1 st to the 5 th thoracic vertebra, the back was obtained with a cut from the 1 st lumbar vertebra to the 1 st sacral vertebra, thus obtaining two cuts per carcass.

During the cutting of the carcass, the loin (Longissimus lumborum) was obtained. The samples were vacuum packed, identified with labels and kept in refrigeration at $4^{\circ} \mathrm{C}$ until the physical-chemical and sensorial analyses were performed.

Table 2: Influence of corn forage type and flaxseed level on growth performance response of feedlot Pelibuey lambs

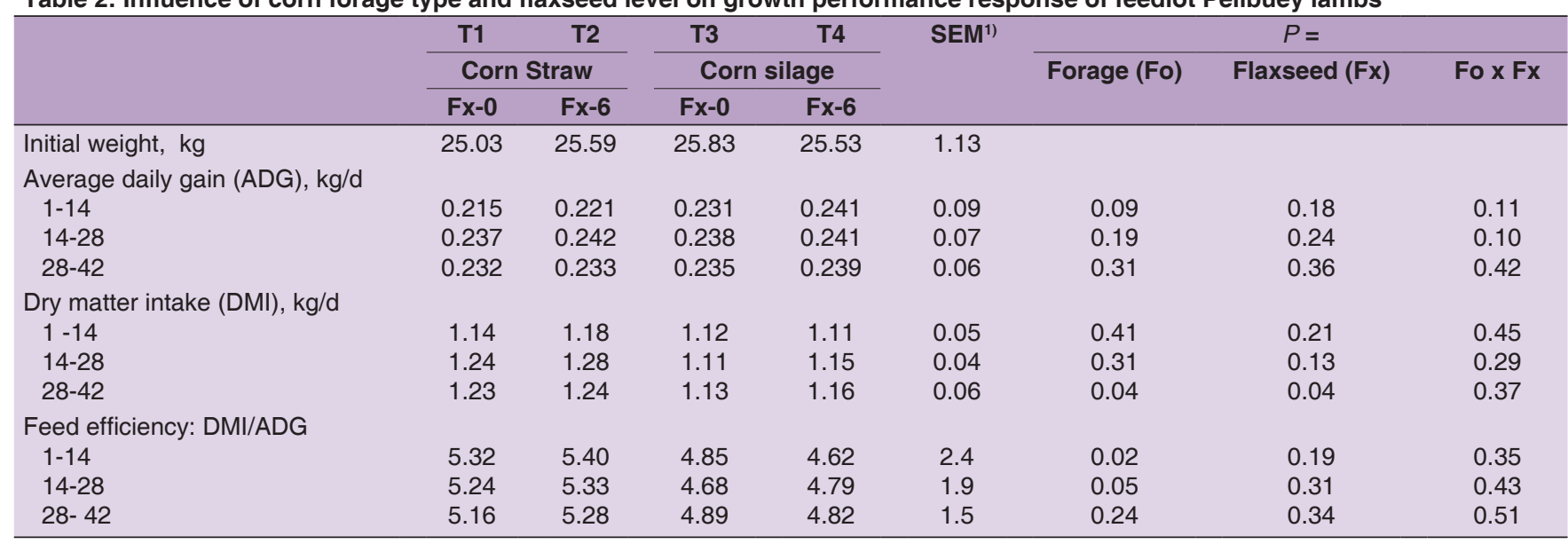

1) Standard error of the means. 
Ramírez, et al

Table 3: Influence of corn forage type and flaxseed (Fx) level on carcass characteristics of feedlot Pelibuey lambs

\begin{tabular}{|c|c|c|c|c|c|c|c|c|}
\hline & T1 & T2 & T3 & T4 & \multirow[t]{3}{*}{ SEM $^{11}$} & \multicolumn{3}{|c|}{$P=$} \\
\hline & \multicolumn{2}{|c|}{ Corn Straw } & \multicolumn{2}{|c|}{ Corn silage } & & Forage (Fo) & Flaxseed (Fx) & Fo $x \mathrm{Fx}$ \\
\hline & Fx-0 & Fx-6 & $F x-0$ & Fx-6 & & & & \\
\hline Carcass hot weight, kg & 21.08 & 21.02 & 21.49 & 21.52 & 1.02 & 0.11 & 0.23 & 0.65 \\
\hline Carcass cold weight, $\mathrm{kg}$ & 20.9 & 20.6 & 21.44 & 22.68 & 1.01 & 0.04 & 0.45 & 0.56 \\
\hline Commercial dressing, $\%$ & 52.7 & 52.12 & 53.61 & 53.63 & 1.61 & 0.02 & 0.39 & 0.14 \\
\hline Fat thickness over, $\mathrm{mm}$ & 0.81 & 0.90 & 0.92 & 1.06 & .01 & 0.03 & 0.04 & 0.07 \\
\hline
\end{tabular}

Table 4: Influence of corn forage type and flaxseed level on physicochemical characteristics of Pelibuey lamb meat

\begin{tabular}{|c|c|c|c|c|c|c|c|c|}
\hline & T1 & T2 & T3 & T4 & \multirow[t]{3}{*}{ SEM ${ }^{1)}$} & \multicolumn{3}{|c|}{$P=$} \\
\hline & \multicolumn{2}{|c|}{ Corn straw } & \multicolumn{2}{|c|}{ Corn silage } & & Forage (Fo) & Flaxseed (Fx) & Fo $x$ Fx \\
\hline & Fx-0 & Fx-6 & Fx-0 & Fx-6 & & & & \\
\hline Luminosity L & 34.02 & 36.57 & 36.94 & 36.96 & 3.22 & 0.11 & 0.25 & 0.78 \\
\hline Intensity a & 9.82 & 9.54 & 8.91 & 9.35 & 1.26 & 0.54 & 0.45 & 0.38 \\
\hline Brilliance $b$ & 0.42 & 0.55 & 0.34 & 0.36 & 0.01 & 0.01 & 0.64 & 0.71 \\
\hline Meat hardness & 17.9584 & 19.3340 & 19.3171 & 18.3754 & 113.23 & 0.34 & 0.23 & 0.56 \\
\hline $\mathrm{pH}$ & 5.85 & 5.72 & 5.53 & 5.72 & 0.33 & 0.78 & 0.65 & 0.51 \\
\hline Water retention capacity & 38.18 & 40.20 & 43.21 & 37.16 & 6.42 & 0.46 & 0.34 & 0.14 \\
\hline Peroxide index & 5.51 & 5.35 & 5.12 & 4.91 & 0.37 & 0.15 & 0.35 & 0.81 \\
\hline Emulsion capacity & 75.41 & 76.91 & 92.7 & 89.21 & 0.6 & 0.02 & 0.07 & 0.35 \\
\hline
\end{tabular}

1)Standard error of the means

Table 5: Influence of corn forage type and flaxseed level on sensorial analysis of Pelibuey lamb meat

\begin{tabular}{|c|c|c|c|c|c|c|c|c|}
\hline & T1 & T2 & T3 & T4 & \multirow[t]{3}{*}{ SEM ${ }^{1)}$} & \multicolumn{3}{|c|}{$P=$} \\
\hline & \multicolumn{2}{|c|}{ Corn straw } & \multicolumn{2}{|c|}{ Corn silage } & & Forage (Fo) & Flaxseed (Fx) & Fo $x$ Fx \\
\hline & Fx-0 & Fx-6 & Fx-0 & Fx-6 & & & & \\
\hline General quality & 8.11 & 7.73 & 8.72 & 9.21 & 2.11 & 0.03 & 0.76 & 0.65 \\
\hline Flavor & 7.23 & 7.91 & 8.01 & 8.23 & 2.52 & 0.04 & 0.67 & 0.29 \\
\hline Lamb odor intensity & 9.35 & 9.12 & 7.11 & 7.42 & 2.13 & 0.02 & 0.34 & 0.56 \\
\hline Color & 8.33 & 8.12 & 8.45 & 8.96 & 2.15 & 0.45 & 0.27 & 0.76 \\
\hline Juiciness & 7.52 & 7.12 & 9.48 & 9.61 & 2.31 & 0.02 & 0.47 & 0.37 \\
\hline Softness & 9.41 & 9.92 & 9.51 & 9.44 & 2.82 & 0.54 & 0.21 & 0.56 \\
\hline
\end{tabular}

1)Standard error of the means

Chemical analysis and instrumental measurement

Chemical analysis: The feed samples consumed by the animals were analyzed in Dry Matter (DM), ash, total nitrogen (by the Kjeldahl method) (AOAC 1990) and Neutral Detergent Fiber (NDF) (Weizhong and Udén 1998).

Meat colour: Piece of meat were cuts of $2.5 \mathrm{~cm}$ and Chroma meter (Hunter Lab, Chromameter CR-410, Konica Minolta Sensing, Inc. Japan) was used to determine the colour and chromatic values were reported as $\mathrm{L}^{*}, \mathrm{a}^{*}, \mathrm{~b}^{*}$, and shades (tan-1b/an angle and magnitude $((\mathrm{a} 2+\mathrm{b} 2) 1 / 2) \mathrm{g})$.

Meat hardness: Pieces of meat were cut perpendicular to the direction of the muscle fibers, and boiled in distilled water at $80^{\circ} \mathrm{C}$ by $20 \mathrm{~min}$. Subsequently, cuts of $2.5 \mathrm{~cm}$ thickness were made. Shear force values were determined on meat cuts of $2.5 \mathrm{~cm}$ thickness using a Warner-Bratzler shear in a TA-XT2 texture analyser (Texture Technologies Corp., Scarsdale, NY), at $5 \mathrm{~mm}$ test speed and $5 \mathrm{~mm} / \mathrm{g}$ backing speed, being applied $0.981 \mathrm{~N}$ force (Ishihara et al. 2013). $p H$ : Meat samples were placed in a $200 \mathrm{~mL}$ beaker, $100 \mathrm{~mL}$ of distilled water was added and ground in a blender for 1 min. The potentiometer was standardized with a phosphate buffer solution

Water retention capacity (WRC): Ten grams of sample were deposited in the $30 \mathrm{~mL}$ centrifuge tube in duplicates. To each tube $16 \mathrm{~mL}$ of $0.6 \mathrm{M} \mathrm{NaCl}$ solution was added and stirred for one min. The tubes were placed in an ice bath for $30 \mathrm{~min}$, with continuous agitation (Goga et al., 2012).

Peroxide index: It is defined as the amount of peroxides in the sample that cause the oxidation of potassium iodide (expressed in milli equivalent of active oxygen per $\mathrm{kg}$ of fat). Five grams of fatty tissue were added in $30 \mathrm{~mL}$ of a mixture of acetic acid and chloroform (3:2). The calculation was reported in $\mathrm{mL}$ of thiofulfate per gram of meat, using the following equation: Index of peroxide (IP) $=(((\mathrm{mL}$ thiosulfate $\mathrm{x}$ N (0.01)) x 1000) / g sample). 
Emulsion capacity: Meat homogenate $(32.5 \mathrm{~mL})$ plus $75 \mathrm{ml}$ of sunflower oil, and $97.5 \mathrm{ml} 0.45 \mathrm{M} \mathrm{NaCl}$ solution were deposited in the blender (Oster M6798) jar. At $6000 \mathrm{rpm}$, $100 \mathrm{~mL}$ oil was added at a rate of $0.5 \mathrm{~mL} / \mathrm{sec}$. After the oil had been added, the emulsion was stirred for an additional $5 \mathrm{sec}$. The electrical conductivity during the emulsification was recorded by a microprocessor and the total of the added oil before and after emulsification was recorded as emulsion capacity (Kurt and Ceylan, 2018).

\section{Sensorial analysis}

The QDA method (Quantitative Descriptive Analysis) was used on the meat samples (ISO 13299.2 2003). Samples were placed on a grill for roasting on a stove, exposing the meat to medium heat $\left(120^{\circ} \mathrm{C}\right)$ for five min per side, repeating the operation sometimes for $15 \mathrm{~min}$. Subsequently were presented to the panelists in the form of cubes, (approximately $1.5 \mathrm{~cm}^{3}$ ) to be evaluated on a structured scale of 1 to $15 \mathrm{~cm}$. The collaboration of 30 panelists $(30 \times 4$ treatments $=120$ meat samples $)$ previously trained in sensory analysis (students of the 9th and 10th grade of the degree of Veterinary Medicine). The panel members were seated in individual stands in a room with controlled temperature and light, receiving a set of four samples (one per treatment) served in randomized order. Water and crackers were used to cleanse palate to remove residual flavors, between samples and at the beginning of the session. The attributes evaluated to the meat were: 1) general quality, 2) flavor, 3) juiciness, 4) odor and 5) softness. The panelists were asked to mark their horizontal perception of each variable (value of zero, as lousy) on a horizontal line of $15 \mathrm{~cm}$ long. Distances were measured and each variable was reported in centimeters at the distance from the zero point (Guerrero et al., 2002).

\section{Statistical analysis}

The following statistical model included effects of forage type (Fo: corn straw and corn silage), flaxseed level (Fx: cero and 6\%) and (Fo x Fx) was used:

$$
\mathrm{Y}_{\mathrm{ij} \mathrm{j}}=\mu+\mathrm{FO}_{\mathrm{i}}+\mathrm{Fx}_{\mathrm{j}}+\mathrm{Fo}_{\mathrm{i}} \mathrm{Fx}_{\mathrm{j}}+\mathrm{e}_{\mathrm{ijk}}
$$

Where:

$\mathrm{Y}_{\mathrm{ijk}}=$ variable of response of the productive performance, carcass and meat quality.

$\mu=$ average population.

$\mathrm{Fo}_{\mathrm{i}}=$ effect of the forage type.

$\mathrm{Fx}_{\mathrm{j}}=$ effect of the flaxseed level block.

$\mathrm{Fo}_{\mathrm{i}} \mathrm{Fx}_{\mathrm{i}}=$ effect of the interaction of random groups, feed types and fixed terms.

$\mathrm{e}_{\mathrm{ijk}}=$ experimental error.

The study had four groups of lambs selected randomly, housed in four pens per group: 1) fed with corn straw
(CS) and cero percent of flaxseed (Fx-0), 2) fed with corn straw (CS) with $6 \%$ of flaxseed (Fx-6), 3) fed with corn silage (CL) and cero percent of flaxseed ( $\mathrm{Fx}-0)$, and 4) fed with corn silage (CL) and six percent of flaxseed (Fx-6). The effect of the interaction $\left(\mathrm{Fo}_{\mathrm{i}} \times \mathrm{Fx}_{\mathrm{i}}\right)$ was given in all variables. All data are shown with means and standard error means. Significance was declared at $\mathrm{P}<0.05$, and trends were declared at $\mathrm{P}<0.1$. The data collected in this study were subjected to analysis of variance and comparison of averages through contrast, using SAS 9.1 software (SAS Institute Inc., Cary, NC, USA).

\section{RESULTS}

\section{Productive parameters and carcass characteristics}

Table 2 shows the values of the ADG, DM intake and FE of Pelibuey lambs with the different treatments. During the first period of fattening (1-14d) there was a tendency to improve $(5.9 \%, P \leq 0.09)$ the weight with CL. DMI during the whole fattening period improved by $9.2 \%$ with CL $v$ s. $\mathrm{CS}$. The FE improved with the use of CL in the periods of $1-14 \mathrm{~d}(P \leq 0.02)$ and $14-28 \mathrm{~d}(0.05)$ in 11.7 and $10.4 \%$ respectively.

Table 3 shows the variables analyzed on carcass characteristics. The CL improved the weight of the chilled canal, the commercial yield and the cover fat in $6.8 \%(P=0.04), 2.3 \%$ $(P=0.02)$ and $11.5 \%(P=0.03)$, respectively. There was a trend of statistical interaction between the type of forage and $\mathrm{Fx}$ in the cover fat $(P=0.07)$. $\mathrm{CL}$ in the diets during the first 14 days of fattening tended to improve the weight gain and feed intake during the whole fattening phase.

\section{Meat quality}

Table 4 shows the physical-chemical values of the meat of lambs evaluated in different treatments. The $\mathrm{L}$ coordinate (luminosity) did not show significant differences $(P>0.05)$ between the treatments, while the coordinate $b$, (index of yellow to blue: brightness) was increased by $38 \%(P=0.01)$ in the animals fed with CS (CS: 0.70 vs. CL: 0.97). The emulsion capacity increased $19 \%(P=0.02)$ with the CL (CS: 76.16 vs. CL: 90.95). The hardness expressed as resistance to the cut (orientates to the quality of the meat: hardness) and the values of WRC (expressed in $\mathrm{mL}$ of $0.6 \mathrm{M} \mathrm{NaCl}$ retained in $100 \mathrm{~g}$ of meat) did not show significant differences between the treatments. Post-mortem pH meat did not change between treatments. The diet did not affect the cutting force or the loss of water. The average $\mathrm{pH}$ in the meat was 5.7.

\section{Sensorial analysis of meat}

Table 5 shows the values of the sensory analysis in the meat of the lambs evaluated. The attributes evaluated to the meat were: 1) General quality. The CL improved the 
quality in general by $13 \%$ ( $P=0.03$, CS: 7.92 vs. CL: 8.96). 2). Flavor. The taste was increased by 7 ( $P=0.04$ : CS: 7.57 vs. CL: 8.12). 3) Juiciness increased 30\% ( $P=0.02$ : CS: 7.32 vs. CL: 9.54). 4) Odor. The smell of lamb decreased by 12\% ( $P=0.02$ : CS: 9.23 vs. CL: 7.26\%). 5) Softness. The treatments with CS had $2 \%$ more toughness than CL $(P=0.56:$ CS: 9.67 vs. CL: 9.48).

\section{DISCUSSION}

Weight gain and feed intake improvement with CL in the diets, was expected, since CL offers better palatability to the diet consumed (Lee et al., 2009, Minchin et al., 2009, He et al., 2012). The Fx in the diet showed no response in growth performance in this study, other authors observed that Fx processed in different ways, increased the weight of the growing heifer carcass (Maddock et al., 2006). The inclusion of CL increased the energy density of the diet and decreased the NDF content (Table 1), improving the weight and yield of the carcass (Hernández-Calva et al., 2011) and the content of cover fat (Galli, 2008). Other research also cites Fx in the diet increased the fat deposition in growing steers (Drouillard et al., 2002, Aharoni et al., 2004, Kim et al., 2009) and heifers (Maddock et al., 2006).

A pH-hardness ratio is mentioned when the $\mathrm{pH}$ is greater than six (this study obtained 5.7) associated with softness (Purchas 1990). The $\mathrm{pH}$ also has an important influence on the WRC, since it determines the electrical charges of the proteins and therefore the capacity of these to retain the water (Offer and Knight 1988). A similar study carried out in cows of waste was observed less loss of water with CL (Hernández-Calva et al., 2011). The loss of water is influenced by race, age (Fiems et al., 2003) and post mortem factors (Aalhus et al., 2001). The color intensity of the meat decreased with CL, contrary to that observed in cows fed with CL (Hernandez-Calva et al., 2011). Mainly the color differences are associated by the presence of fat and connective tissue (Merera et al., 2010) to light scattering, and associated with the greater loss of water, where the bright red color of fresh meat depends on the amount of the oxy-hemoglobin in the tissue, the rate of oxygen diffusion and the partial pressure of oxygen on the surface of the meat (Beriain et al., 2009). Several authors mention that the susceptibility of meat to oxidation depends on several factors, although one of the most important is the content of polyunsaturated fatty acids in cell membranes (Mir et al., 2004, Realini et al., 2004, Daly et al., 2007). CL and mainly Fx contain more Polyunsaturated fatty acids, which increase the emulsification capacity of fats and give differences in the color of the meat (Gibb et al., 2004, LaBrune et al., 2008).
The inclusion of Fx in the diet of lambs improved the sensory analysis of the meat (Nassu et al., 2011, He et al., 2012) to increase the intensity of unpleasant taste due to the greater fatty acids oxidation (LaBrune et al., 2008) or to present strange flavors, due to the content of linoleic acid and $\alpha$-linolenic acid in fat (He et al., 2012) or meat (Nassu et al., 2011). Studies in lambs, also mention that Fx in the diet increased the formation of some volatile compounds in cooked meat, although this response was less dramatic when the lambs were fed with fish oil (Elmore et al., 2000, Jaworska et al., 2016). According to this study, only 6\% of Fx included in the diet did not induce changes in the sensory analysis, as reported by another study (Nguyen et al., 2017), but when the amount of $10 \%$ of Fx was used, the intensity of unpleasant taste increases (LaBrune et al., 2008); the cause is the high content of n-3 fatty acid contained in $\mathrm{fx}_{\mathrm{x}}$ (Vatansever et al., 2000). It causes a decrease in preferences in the panelists who evaluate in sensory analysis of meat with a high content of unsaturated fatty acids (Dima et al., 2014) and increased in oxidation products (Yang et al., 2002). In this study, the values of general quality, flavor, odor and juiciness were increased with the use of CL. It is evident that the nutritional quality of the supplemented forage influences several parameters of the sensory analysis (DeBrito et al., 2016) as it happened in this study. Other minimum factors that also influence are the chopping process and the homogenization of the meat prepared for the sensory analysis; the causes are variations in the degrees of alteration in the cellular structure, that facilitates the interactions between pro-oxidants and unsaturated fatty acids and the formation of free radicals that can propagate oxidation. Therefore, subtle differences in the meat preparation properties can give differences in meats with CS or CL in the diet.

\section{CONCLUSIONS}

The use of Fx did not influence the physical-chemical and sensory variables of the meat. However, CL favorably influenced the feed intake, some carcass characteristics, the flavor and juiciness of the meat. In the case of the "lamb odor" variable, it was lower and was considered a good attribute for the Latins consumer. Perhaps in other countries as Asia or Europe it is the opposite, the greater intensity in odor is considered an attribute. The results generated from the study, consider encouraging the use of CL in the fattening of lambs, since it presented better attributes in the improvement of the carcass and Pelibuey lamb meat.

\section{Authors contributions}

Diana Tamara Ramirez participated in the feeding of animals and carried out each of the quality tests of 
pelibuey sheep meat. Jose Reyes Galaviz-Rodríguez analyzed the behavioral test of the animals according to the diet. Xochitl Gabriela Montalvo-Aguilar analyzed and collected the samples in the humanitarian death of Pelibuey sheep process. Patricia Villalobos-Peñalosa participated in data collection and statistical analysis. Pablo CortesRoldan performed sensory analysis and coordinated the panelists of pelibuey sheep. Luz Marina Hernandez-Calva performed data analysis was in charge of the overall direction and planning, writing, and interpretation of the manuscript and interpretation of results.

\section{REFERENCES}

Aalhus, J. L., A. M. Janz, A. K. W. Tong, S. D. M. Jones and W. M. Robertson. 2001. The influence of chilling rate and fat cover on beef quality. Can. J. Anim. Sci. 81: 321-330.

Aharoni, Y, A. Orlov and A. Brosh. 2004. Effects of high forage content and oilseed supplementation of fattening diets on conjugated linoleic acid (CLA) and trans fatty acids profiles of beef lipid fractions. Anim. Feed Sci. Tech. 117: 43-60.

AOAC. 1990. Official Methods of Analysis of the AOAC. $15^{\text {th }}$ ed. Methods 932.06, 925.09, 985.29, 923.03. AOAC Arlington, VA, USA.

Beriain, M. J., M. V. Goni, G. Indurain, M. V. Sarries and K. Insausti. 2009. Predicting Longissimus dorsi myoglobin oxidation in aged beef based on early post-mortem colour measurements on the carcass as colour stability index. Meat Sci. 81: 439-445.

Daly, C. M., A. P. Moloney and F. J. Monahan. 2007. Lipid and colour stability of beef from grazing heifers supplemented with sunflower oil alone or with fish oil. Meat Sci. 77: 634-642.

De Brito, G. F., S. R. McGrath, B. W. B. Holman, M. A. Friend, S. M. Fowler, R. J. van de Ven and D. L. Hopkins. 2016. The effect of forage type on lamb carcass traits, meat quality and sensory traits. Meat Sci. 119: 95-101.

Della Malva, A., M. Albenzio, G. Annicchiarico, M. Caroprese, A. Muscio, A. Santillo and R. Marino. 2016. Relationship between slaughtering age, nutritional and organoleptic properties of Altamurana lamb meat. Small Rumin. Res. 135: 39-45.

Dima, F. C. Vizireanu, G. Iordachescu, D. Istrati and M. C. Garnai. 2014. Comparative sensory analysis of products with low animal fat meat compositions. Ann. Univ. Dun. Jos Galati Fasc. Food Technol. 38: 37-47.

Drouillard, J. S., E. J. Good, C. M. Gordon, T. J. Kessen, M. J. Sulpizio, S. P. Montgomery and J. J. Sindt. 2002. Flaxseed and Flaxseed Products for Cattle: Effects on Health, Growth, Performance, Carcass Quality and Sensory Attributes. Proceeding $59^{\text {th }}$ Flax Institute, ND, USA, Fargo, pp. 72-87.

Elmore, J. S., D. S. Mottram, M. Enser and J. D. Wood. 2000. The effects of diet and breed on the major volatiles present in lamb aroma. Meat Sci. 55: 149-159.

FAO. 2013. Current Worldwide Annual Meat Consumption Per Capita, Livestock and Fish Primary Equivalent. Tech Report FAO N $3-4252$, Food and Agriculture Organization of the United Nations, Rome, Italy.

Fiems, L. O., S. De Campeneere, W. Van Caelenbergh, J. L. De Boever and J. M. Vanacker. 2003. Carcass and meat quality in doublemuscled Belgian Blue bulls and cows. Meat Sci. 63: 345-352.

French, P., C. Stanton, F. Lawless, E. G. O'Riordan, F. J. Monahan, P. J. Caffrey and A. P. Moloney. 2000. Fatty acid composition, including conjugated linoleic acid, of intramuscular fat from steers offered grazed grass, grass silage, or concentrate-based diets. J. Anim. Sci. 78: 2849-2855.

Galli, I., G. Teira, F. Perlo, P. Bonato, O. Tisocco, A. Monje and S. Vittone. 2008. Animal performance and meat quality in cull cows with early weaned calves in Argentina. Meat Sci. 79: 521-528.

Gibb, D. J., F. N. Owens, P. S. Mir, Z. Mir, M. Ivan and T. A. McAllister. 2004. Value of sunflower seed in finishing diets of feedlot cattle. J. Anim. Sci. 82: 2679-2692

Goga, C. B., A. G. Fermani and S. Barbera. 2012. Meat quality and slaughtering techniques. Ind. Aliment. 52: 18-24.

Guerrero, L. I., A. E. Ponce and M. L. Pérez. 2002. Curso Práctico de Tecnología de Carnes y Pescado. UAM, U-I, México, DF.

He, M. L., T. A. McAllister, P. S. Kastelic, Mir, J. L. Aalhus, M. E. R. Dugan and N. Aldai. 2012. Flaxseed supplementation of hay- and silage-based diets concentrations of alpha-linoleic acid and its biohydrogenation intermediates in beef cow subcutaneous fat. J. Anim. Sci. 90: 592-604.

Hernández-Calva, L. M., M. He, M. Juarez, J. L. Aalhus, M. E. R. Dugan and T. A. McAllister. 2011. Effect of flaxseed and forage type on carcass and meat quality of finishing cull cows. Can. J. Anim. Sci. 91: 613-622.

Ishihara, Y., R. Moreira, G. de Souza, A. Salviano and M. Madruga. 2013. Study of the warner-bratzler shear force, sensory analysis and sarcomere length as indicators of the tenderness of sundried beef. Molecules. 18: 9432-9440.

ISO 13299.2. 2003. Sensory Analysis Methodology-General Guidance for Establishing a Sensory Profile. International Organization for Standardization, Switzerland, British Standard BSI.

Jaworska, D, M. Czauderna, W. Przybylski and A. J. RozbickaWieczorek. 2016. Sensory quality and chemical composition of meat from lambs fed diets enriched with fish and rapeseed oils, carnosic acid and selenocompounds. Meat Sci. 119: 185-192.

Kim, C., J. Kim, Y. Oh, E. Park, G. Ahn, G. Lee, J. Lee and K. Park. 2009. Effects of flaxseed diets on performance, carcass characteristics and fatty acid composition on Hanwoo steers. Asian Aust. J. Anim Sci. 22: 1151-1159.

Kurt, S. and H. G. Ceylan. 2018. Effects of flaxseed and pH on the emulsion properties of beef by using a model system. Turk. J. Agric. Food Sci. Technol. 6: 78-83.

Lee, M. R. F., P. R. Evans, G. R. Nute, R. I. Richardson and N. D. Scollan. 2009. A comparison between red clover silage and grass silage feeding on fatty acid composition, meat stability and sensory quality of the M. Longissimus muscle of dairy cull cows. Meat Sci. 81: 738-744.

Maddock, T. D., M. L. Bauer, K. B. Koch, V. L. Anderson, R. J. Maddock, J. Barcelo, G. Coblijn, E. J. Murphy and G. P. Lardy. 2006. Effect of processing flax in beef feedlot diets on performance, carcass characteristics, and trained sensory panel ratings. J. Anim. Sci. 84: 1544-1551.

Merera, C., G. Abebe, A. Sebsibe and A. L. Goetsch. 2010. Effects and interactions of origin of sheep in Ethiopia (Highland vs Lowland areas), feeding, and lengths of rest and feeding on harvest measures. J. Appl. Anim. Res. 37: 33-42.

Minchin, W., F. Buckley, D. A. Kenny, F. J. Monahan, L. Shallooand and M. O'Donovan. 2009. Effect of grass silage and concentrate based finishing strategies on cull dairy cow performance, carcass and meat quality characteristics. Meat Sci. 81: 93-101.

Mir, P. S., T. A. McAllister, S. Scott, J. Aalhus, V. Baron, D. McCartney, E. Charmley, L. Goonewardene, J. Basarab, E. Okine, R. J. Weselake and Z. Mir. 2004. Conjugated linoleic acid enriched beef production. Am. J. Clin. Nutr. 79: 1207-1211. 
Nassu, R. T., M. E. R. Dugan, M. L. He, T. A. McAllister, J. L. Aalhus, N. Aldai and J. K. G. Kramer. 2011. The effects of feeding flaxseed to beef cows given forage based diets on fatty acids of longissimus thoracis muscle and backfat. Meat Sci. 89: 469-77.

Nguyen, D. V., A. R. Flakemore, J. R. Otto, S. W. Ives, R. W. Smith, P. D. Nichols and A. E. O. Malau-Aduli. 2017. Nutritional value and sensory characteristics of meat eating quality of Australian prime lambs supplemented with pelleted canola and flaxseed oils: fatty acid profiles of muscle and adipose tissues. Int. Med. J. 3: 1-21.

Offer, G. and P. Knight. 1988. The structural basis of water-holding in meat. Part 2: Drip losses. In: R. Lawrie (Ed.), Developments in Meat Science. Elsevier Applied Science, London, England, pp. 173-243.

Purchas, R. W. 1990. An assessment of the role of $\mathrm{pH}$ differences in determining the relative tenderness of meat from bulls and steers. Meat Sci. 27: 129-140.
Realini, C. E., S. K. Duckett, G. W. Brito, R. M. Dalla and D. De Mattos. 2004. Effect of pasture vs. concentrate feeding with or without antioxidants on carcass characteristics, fatty acid composition, and quality of Uruguayan beef. Meat Sci. 66: 567-577.

SAS. 2008. Statistical Analysis System. SAS/STAT version 9.2. SAS Institute Inc, Cary, NC, USA.

Vatansever, L., E. Kurt, M. Enser, G. R. Nute, N. D. Scollan, J. D. Wood and R. I. Richardson. 2000. Shelf life and eating quality of beef from cattle of different breeds given diets differing in $n-3$ polyunsaturated fatty acid composition. Anim. Sci. 71: 471-482.

Weizhong, C. and P. Udén. 1998. An alternative oven method combined with different detergent strengths in the analysis of neutral detergent fiber. Anim. Feed. Sci. Tech. 74: 281-288.

Yang, A., M. Brewster, S. Beilken, M. Lanari, D. Taylor and R. K. Tume. 2002. Warmed-over flavor and lipid stability of beef: Effects of prior nutrition J. Food Sci. 67: 3309-3313. 